九州大学学術情報リポジトリ

Kyushu University Institutional Repository

A New Approach to Pectin Manufacture by Copper Method : Part 1. Preparation of Pect in Pomace, Pectin Extraction and Concentration by Copper Salt

\title{
Kausar, Pervez
}

Food Processing Laboratory, Faculty of Agriculture, Kyushu University

Nomura, Danj i

Food Processing Laboratory, Faculty of Agriculture, Kyushu University

https://doi.org/10.5109/23720

出版情報: 九州大学大学院農学研究院紀要. 25 (2/3)，pp.61-71，1980-11. Kyushu University バージョン：

権利関係: 
J.Fac. Agr., Kyushu Univ., 25 (2 • 3), 61-71 (1980)

\title{
A New Approach to Pectin Manufacture by Copper Method
}

\author{
Part 1. Preparation of Pectin Pomace, Pectin Extraction \\ and Concentration by Copper Salt
}

\section{Pervez Kausar and Danji Nomura}

Food Processing Laboratory, Faculty of Agriculture, Kyushu University 46-09, Fukuoka 812

(Received A pril 21, 1980)

\begin{abstract}
This study was undertaken purely from processing point of view, hence the conclusions made were also, which better fitted in the process, judged by the experience. It was found that unleached peel can not be dried satisfactorily because of its sticky nature and development of undesirable dark reddish brown color, and that cold leaching seemed more practical than hot leaching when compared on the basis of economy and merits in return. Quality of pectin in citrus material was adversely affected by drying temperature. whereas. moisture contents of the dry pomace and the temperature of peel in its final stage of drying controlled the quality of pectin in the pomace. Yields of cold and hot leached pomace were $11.2 \%$ and $9.6 \%$ respectively and that 7-10\% moisture contained pomace did not show any promising undesirable change during one year of storage when packed in the polythene bags and kept in a dry place. Total extractable pectin yield increased about $3 \%$ and $5 \%$ by cold and hot leaching respectively (due to concentration of pectin in the peel by leaching out other soluble solids), this difference was more promising when yield calculated on qualitative basis. An extract suitable for $\mathrm{Cu}^{2+}$ precipitation (0.50-o. $55 \%$ pectin) was obtained by extracting one part weight of pomace with 40 parts of $0.13 \% \mathrm{HCl}$ solution (extract $\mathrm{pH} 1.7$ ) for $45 \mathrm{~min}$ utes at $95^{\circ} \mathrm{C}$. Best $\mathrm{Cu}$-pectin precipitates were obtained when $20 \mathrm{mg}$ of $\mathrm{Cu}^{2+}$ as $\mathrm{CuCl}_{2}$ was added in $100 \mathrm{ml}$ of $0.50-0.55 \%$ pectin contained extract and then $\mathrm{pH}$ was adjusted at 2.8 with conc. $\mathrm{NH}_{4} \mathrm{OH}$, after cooling the mixture to about $20^{\circ} \mathrm{C}$.
\end{abstract}

\section{INTRODUCTION}

Annual production of Unshu citrus in Japan in the year 1978-79 was about $35.4 \times 10^{6}$ tons, out of which $8 \times 10^{6}$ was processed and the remaining consumed as fresh. Processing leaves behind about $50 \%$ of its weight as waste in the form of peel, which at present is dried in the direct fire-rotary dryer after mixing with calcium oxide and in turn is used as animal feed. At present drying cost of peel is higher than the price fetched from the sale of dry peel as a feed, this burden on the orange juice industry is increasing day by day due to gradual increase in the energy cost. In such circumstances, processor of citrus fruit is left with no choice but to utilize this peel to produce other useful products out of it, and this way cut the cost of its disposal as a feed.

Unshu citrus peel contains about $15 \%$ pectin on dry basis (D. B.) which 
shows Japan has a potential to produce enough pectin, which will meet not only the domestic needs but can be exported as well, whereas, at present all the pectin used in various food industries is imported one. Keeping in view these facts this study is undertaken as a first step towards pectin production.

To handle the bulk volume of peel and to run the pectin industry throughout the year, there is no other way but to preserve and stabilize peel by drying (pomace manufacture). Rouse $(1967,1977)$ and Rouse and Crandall (1978) had reported data on the quality of pectin extracted from the commercially dried citrus pomace. Shepherd and Graham (1952) studied the effect of drying on the quality of pectin by using two temperatures in two stage drying in a forced draft oven. Crandall et al. (1978) published results on the pectin pomace manufacture by using a direct fire rotary dryer at different inlet air temperatures.

To extract pectin from the pomace, which exists as insoluble protopectin within the pomace, it is necessary to convert it into soluble pectin by acid or enzymatic treatment, if it is required to prepare powdered pectin. Up to now almost all the mineral acids have been tried to extract pectin (Huang, 1973). Recently, Rouse and Crandall (1978) extracted pectin from lime and lemon peel by nitric acid. Acid extraction is actually a compromise between $\mathrm{pH}$, time and temperature, to extract maximum pectin by least affecting its quality, keeping in view the handling problem, equipment available and economy etc. Kaseem (1969) used ionizing radiation for hydrolysis of pectin and studied their effect on the properties of extracted pectin. Commercially hydrochloric acid, sulfurous acid and sulfuric acid are being used for extraction of pectin depending upon the producer's choice and modification of final product. Sakai et al. (1978) used protopectinase to hydrolyze protopectin.

After extraction and clarification of pectin solution it needs to be concentrated, which is one of the most expensive step within the pectin manufacture process. 3-4\% pectin concentrate can be efficiently and economically precipitated in the alcohol, being insoluble in the organic solvent, whereas concentration of pectin in the extract is extremely low. Up to date concentration on commercial scale is done by vacuum evaporation and aluminum precipitation method, throughout the world, depending upon the choice and economical position of the producer. In this study concentration of pectin extract will be done by making $\mathrm{Cu}$-pectin complex initiated by Nomura and Naito $(1953,1955)$, which seemed to have following advantages over aluminum method :

a) Quantity of $\mathrm{Cu}^{2+}$ required to form 3-4 \% concentrate is extremely low as compared to aluminum.

b) $\mathrm{Cu}^{2+}$ can combine with pectin even in very dilute pectin extract.

c) $\mathrm{Cu}$-pectin precipitate is very sensitive to $\mathrm{pH}$ and temperature and can easily be changed into solution, which might favor the next demetaling step. 


\section{MATERIALS AND METHODS}

\section{A. Preparation of pectin pomace}

Unshu citrus peel was obtained from Fukuoka-ken Engeiren Amagi Mikan Juice Factory during 1977-78 and 1978-79 at optimum harvest seasons (mid of Nov. to the end of Dec.) after juice extraction by inline juice extractor. Peel was divided into three parts, two parts were cold and hot leached according to the following method.

Cold leaching : One part of the peel was mixed with three parts of tap water $(\mathrm{v} / \mathrm{v})$ for 20 minutes in a batch process.

Hot leaching : One part of peel was mixed with 3 parts of hot water at $75^{\circ} \mathrm{C}$ and mixed for 15 minutes.

In both the cases cold and hot leached peels were drained on a screen and excess water was removed by a filter type centrifuge. All the three parts of peel were dried according to the scheme shown in Fig. 1 using a forced draft air oven by evenly spreading peel on a wire screen and drying pomace to 7-10\% and 3-5\% moisture for a predetermined time.

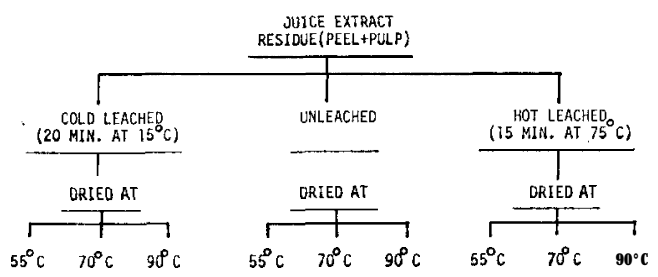

Fig. 1. Experimental layout.

Pectin was extracted from the pomace with 40 times by weight of acidified water $(0.13 \% \mathrm{HCl})$ for 45 minutes at $85^{\circ} \mathrm{C}$.

Chemical and qualitative analyses :

1) Pectin yield was reported as dry alcohol precipitate.

2) Jelly was prepared according to the method described by IFT Committee on Pectin Standardization (1959).

3) Jelly rupture point was measured by curd meter.

4) 150 grade pectin yield was calculated by the

$$
\text { formula }=\frac{\text { Extractable pectin } \times \text { Rupture point of sample Jelly }}{\text { Rupture point of } 150 \text { grade pectin }} .
$$

5) Relative consistancy was measured by Ostwald pipette with a discharge time of $68 \mathrm{sec}$. for distilled water at $30^{\circ} \mathrm{C}$ according to the formula $=t_{s} / t_{0}$, where $t_{s}$ represents discharge time for $0.5 \%$ pectin solution and $t_{0}$ discharge time for distilled water.

6) Apparent molecular weight was calculated by the formula $=\frac{6\left\{\left(t_{s} / t_{0}\right)^{1 / 6}-1\right)}{4.7 \times 10^{-5} \mathrm{C}}$ described by Kim et al. (1978). 
7) All other analyses were made according to AOAC (1960) and methods used at West Regional Research Laboratory, California; for extraction and analysis of pectic materials (Owens et al., 1952).

\section{B. Extraction of pectin from pectin pomace}

Pectin was extracted with $0.1-\mathrm{O}$. $25 \% \mathrm{HCl}$ for $30-60$ minutes at $85-100^{\circ} \mathrm{C}$, and yield was reported as dry alcohol precipitate. Pectin pomace and acidified water ratio from $1: 30$ to $1: 60$ were tried.

\section{Preparation of Cu-pectin complex}

Different precipitation trials were run to find out the best precipitation conditions by adding varying amounts of $\mathrm{Cu}^{2+}$ using $\mathrm{CuCl}_{2} \cdot 2 \mathrm{H}_{2} \mathrm{O}$ solution in a known volume of pectin extract cooled to $20^{\circ} \mathrm{C}$, and then $\mathrm{pH}$ was adjusted by drop wise adding conc. $\mathrm{NH}_{4} \mathrm{OH}$ solution till precipitate appeared ( $\mathrm{pH} 2$. S), during alkali addition solution was constantly mixed at slow speed.

\section{RESULTS}

\section{Pectin pomace manufacture}

Comparison of proximate composition (Table 1) showed that crude protein and pectin contents were higher and crude fat and ash contents were lower in the year 1977-78 than 1978-79. Pectin contents, crude fiber and pentose increased, whereas crude fat and crude protein decreased after cold leaching.

Table 1. Proximate composition of fresh and cold leached peel (fresh basis). Average of at least three batches.

\begin{tabular}{|c|c|c|c|c|c|c|c|c|c|}
\hline Sampling & & & & Crude & Protein & & \multicolumn{3}{|c|}{ N F E } \\
\hline year & Treatment & $\begin{array}{c}\text { Moisture } \\
\text { (\%) }\end{array}$ & $\begin{array}{l}\text { fiber } \\
(\not 6)\end{array}$ & $\begin{array}{l}\text { fat } \\
(\%)\end{array}$ & $\begin{array}{c}\mathrm{N} \times 6.25 \\
(\%)\end{array}$ & $\begin{array}{l}\text { Ash } \\
(\%)\end{array}$ & $\begin{array}{l}\text { Pectin } \\
\text { (a) }\end{array}$ & $\begin{array}{l}\text { Pentose } \\
\text { (b) }\end{array}$ & $\begin{array}{l}\mathrm{NFE}- \\
(\mathrm{a}+\mathrm{b})\end{array}$ \\
\hline $1977-78$ & fresh & 84.5 & 2.61 & 0.21 & 2.38 & 0.58 & 2.32 & 2.53 & 4.87 \\
\hline $1978-79$ & fresh & 33.6 & & 0.30 & 2.26 & 0.62 & 2.30 & 2.61 & \\
\hline $1977-78$ & cold leached & 85.2 & 2.72 & 0.12 & 1.97 & 0.48 & 3.0 & 2.82 & 3.68 \\
\hline
\end{tabular}

Table 2. Percent yield of pectin pomace from fresh peel in the years 1977-78 and 1978-79 (dry basis). Average of more than $300 \mathrm{~kg}$ in each case.

\begin{tabular}{|c|c|c|c|c|c|}
\hline \multirow{2}{*}{$\begin{array}{c}\text { Untreated } \\
(\mathrm{kg}) \\
\end{array}$} & \multicolumn{2}{|r|}{ Cold leached } & \multicolumn{3}{|c|}{ Hot leached } \\
\hline & $\begin{array}{r}\text { Yield } \\
(\mathrm{kg})\end{array}$ & $\begin{array}{c}\text { Soluble solids of drain } \\
(\%)\end{array}$ & $\begin{array}{c}\text { Yield } \\
(\mathrm{kg})\end{array}$ & Soluble & $\begin{array}{l}\text { solids of drain } \\
(\%)\end{array}$ \\
\hline 17. 1 & 11.2 & 1.5 & 9.63 & & 2.0 \\
\hline
\end{tabular}

Pomace yields of unleached, cold and hot leached peels are shown in Table 2, which showed that hot leached drain had higher soluble solids $(2.0 \%)$ than cold leached drain $(1.5 \%)$. Yields of cold and hot leached peel pomace were almost $65.1 \%$ and $56.3 \%$ of the unleached pomace.

Effect of leaching and drying on the total extractable pectin is shown in 


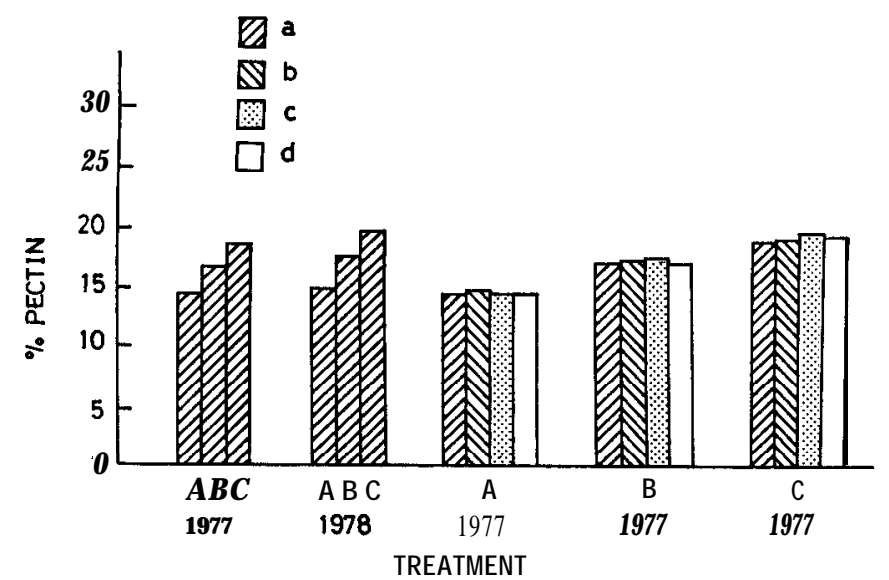

Fig. 2. Effect of leaching and drying on the total extractable pectin (dry basis). A : Unleached, B : Cold leached, C : Hot leached.

a : 80-85 \% moisture (fresh).

b : 7-10\% moisture (dried at $55^{\circ} \mathrm{C}$ ).

c : $7-10 \% 6$ moisture $\left(\right.$ dried at $70^{\circ} \mathrm{C}$ )

$\mathrm{d}: 3-5,6$ moisture (dried at $90^{\circ} \mathrm{C}$ ).

Fig. 2. Results revealed that drying at $55^{\circ} \mathrm{C}, 70^{\circ} \mathrm{C}$ and $90^{\circ} \mathrm{C}$ to a moisture content of 7-10\% and 3-5\% did not affect at all, the extractability of pectin in all the cases (unleached, cold and hot leached pomace), whereas amount of extractable pectin increased to about $2.5 \%$ and $5.0 \%$ after cold and hot leaching respectively. When amount of extractable pectin calculated on 150 grade pectin basis (Fig. 3), result showed that pectin extracted from unleached pomace dried at $90^{\circ} \mathrm{C}$ was most affected and yield decreased $20 \mathrm{Sd} 2 \%$ when dried to 3-5\% moisture and $10 \mathrm{Sd} 2.9 \%$ when dried to 7-10 \% moisture at $55^{\circ} \mathrm{C}$, as compared to fresh peel. In case of cold leaching loss on the basis of total extractable pectin was maximum $26.6 \mathrm{Sd} 2.3 \%$ when dried to $3-5 \%$ moisture at $90^{\circ} \mathrm{C}$ and minimum $16.6 \mathrm{Sd} 1.2 \%$ when dried to 7-10\% moisture at $55^{\circ} \mathrm{C}$, as compared to fresh leached peel, whereas, in case of hot leached pomace loss was maximum, $34.2 \mathrm{Sd} 2.6 \%$ when dried to 3-5\% moisture at $90^{\circ} \mathrm{C}$ and minimum $19.6 \mathrm{Sd} 3 \%$ in case of pomace dried at $55^{\circ} \mathrm{C}$ to $7-10 \%$ moisture. Comparison of consistency of $0.5 \%$ pectin solutions made from pectins extracted from differently treated and dried pomace are shown in Fig. 4, results showed that consistency dropped to almost $1 / 2$ on drying. Qualitative analyses of pectins prepared from differently treated and dried pomace are reported in Table 3. Data showed that purity of pectins prepared from pomace when judged on the basis of anhydrogalacturonic acid ranged between 85-91 Sd 2-4 $\%$, and equivalent weights ranged between 930 and $1162.76 \mathrm{Sd} 0.1 \%$. Methoxyl contents of pectins showed that Unshu citrus peel pectin falls under high methoxyl pectin category (methoxyl contents more than $7.0 \%$ ) having a degree of esterification between 45.6 and $54.5 \mathrm{Sd} 1.2 \%$. Apparent molecular weight 


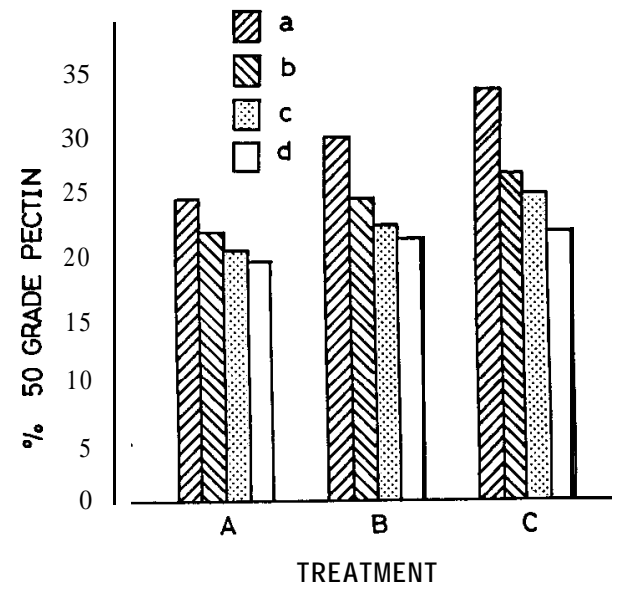

Fig. 3. Effect of leaching and drying on the qualitative yield (dry basis). A : Unleached, B : Cold leached, C : Hot leached. a $: 80-85 \%$ moisture (fresh).

b : $7-10 \%$ moisture (dried at $55^{\circ} \mathrm{C}$ ).

c : $7-10 \%$ moisture (dried at $70^{\circ} \mathrm{C}$ ).

$\mathrm{d}: 3-5 \%$ moisture $\left(\mathrm{dried}\right.$ at $\left.90^{\circ} \mathrm{C}\right)$.

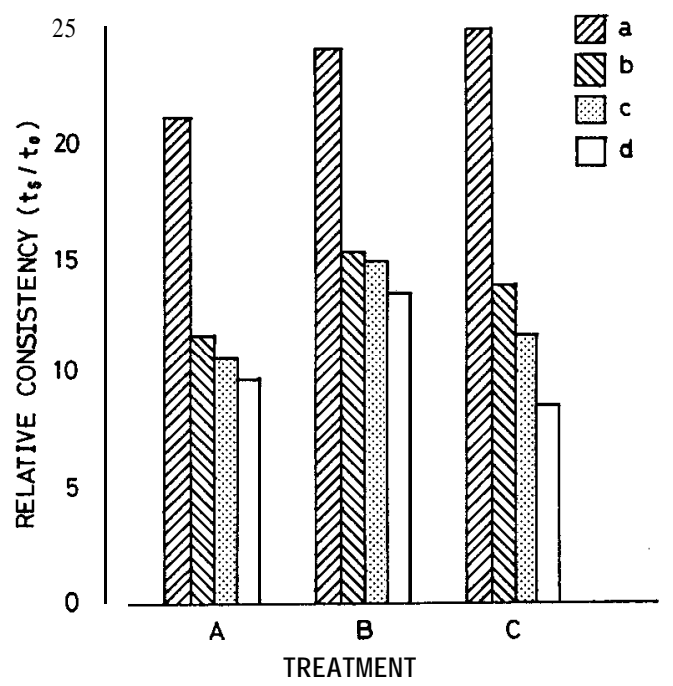

Fig. 4. Comparison of the consistency of $0.5 \%$ pectin solutions made from pectins extracted from differently treated and dried pomace.

$t_{s}:$ discharge time for $0.5 \%$ pectin solution.

$t_{0}:$ discharge time for distilled water.

Symbols used are same as in Figs. 2 and 3. 
Table 3. Qualitative analysis of pectins prepared from differently treated and dried pomace (dry basis).

\begin{tabular}{|c|c|c|c|c|c|c|c|}
\hline Treatment & $\begin{array}{l}\text { Drying } \\
\text { temp. } \\
\left({ }^{\circ} \mathrm{C}\right)\end{array}$ & $\mathrm{AGA}^{1)}$ & $\begin{array}{l}\text { Equivalent } \\
\text { weight }\end{array}$ & $\begin{array}{l}\text { Methoxyl } \\
\text { contents } \\
(\%)\end{array}$ & $\begin{array}{l}\text { Degree of } \\
\text { esterifica- } \\
\text { tion } \\
(96)\end{array}$ & $\begin{array}{c}\text { Apparent } \\
\text { molecular } \\
\text { weight } \\
(\mathrm{kg} \text { mole-r) }\end{array}$ & $\begin{array}{c}\text { Jelly } \\
\text { rupture } \\
\text { point } \\
\left(\mathrm{g} / \mathrm{cm}^{2}\right) \\
\end{array}$ \\
\hline \multirow[t]{2}{*}{ Unleached } & $\begin{array}{l}\overline{55} \\
70\end{array}$ & $9 B .70$ & 1168.66 & 8.40 & 51.47 & 262.3 & \multirow{2}{*}{$\begin{array}{l}50 \\
45 \\
42 \\
40\end{array}$} \\
\hline & 90 & 90.7590 .75 & 1098.901074 .57 & 8.187 .83 & 50.1247 .98 & 157.7148 .3 & \\
\hline \multirow[t]{2}{*}{ Cold leached } & $\begin{array}{l}- \\
55 \\
70\end{array}$ & $\begin{array}{l}88.25 \\
87.00\end{array}$ & $\begin{array}{l}1161.30 \\
1070.57\end{array}$ & $\begin{array}{l}8.45 \\
7.57\end{array}$ & $\begin{array}{l}51.78 \\
47.61\end{array}$ & $\begin{array}{l}194.6 \\
147.3\end{array}$ & \multirow{2}{*}{$\begin{array}{l}52 \\
43 \\
40 \\
37\end{array}$} \\
\hline & 90 & 88.5087 .75 & 1007.60 992.99 & 7.637 .77 & 46.7546 .38 & 142.7131 .7 & \\
\hline \multirow[t]{2}{*}{ Hot leached } & $\begin{array}{l}-5 \\
55 \\
70 \\
90\end{array}$ & $\begin{array}{l}85.50 \\
86.00\end{array}$ & $\begin{array}{r}1090.45 \\
974.17 \\
93431930.09\end{array}$ & $\begin{array}{l}8.54 \\
7.89 \\
774563\end{array}$ & $\begin{array}{l}51.33 \\
46.75\end{array}$ & $\begin{array}{l}211.4 \\
163.2\end{array}$ & \multirow[t]{2}{*}{$\begin{array}{l}53 \\
42 \\
39 \\
35\end{array}$} \\
\hline & 90 & 88.7591 .00 & 934.31930 .09 & 7.7 .4563 & 45.6544 .47 & 146.9129 .8 & \\
\hline
\end{tabular}

1) Anhydrogalacturonic acid.

2) Jelly rupture point of standard 150 grade pectin $30.0 \mathrm{~g} / \mathrm{cm}^{2}$.

in case of pectins prepared from unleached, cold and hot leached pomace ranged between 148.3 to 209.3 , 131.7 to 194.6 and 129.8 to 211.4 kg mole-' respectively. Molecular weight decreased about $60,000-80,000$ from maximum to minimum value in all the cases after drying. Force required to rupture test jellies measured by curd meter was between $35-50 \mathrm{~g} / \mathrm{cm}^{2} \mathrm{Sd} 1-2 \%$ in all the pectins. Results showed that higher molecular weight pectins formed more firm jellies.

\section{Extraction of pectin}

Number of pectin extraction trials were run to find out a suitable combination of time, temperature and $\mathrm{pH}$, which will give a pectin extract of suitable concentration for copper method. Results are reported in Table 4. Results revealed that at $85^{\circ} \mathrm{C}$ only $85 \%$ of total extractable pectin was obtained even when extracted for a prolonged period of time $(60 \mathrm{~min}$.$) at \mathrm{pH} 1.6$, and when temperature was increased to $95^{\circ} \mathrm{C}$ for the same length of time and at same $\mathrm{pH}$, value increased to $97.5 \%$, the next highest yield with minimum acid and energy input was obtained when extracted at $95^{\circ} \mathrm{C}$ for 45 minutes at $\mathrm{pH}$ 1.7. Concentration of pectin in the extract increased to double by decreasing acidified water to pomace ratio from 60 to 30 , at the same time loss of pectin in the residue left after separation of extract, increased from $12-14 \%$ to $20-21$ $\%$.

\section{Cu-pectin precipitation}

The conditions of $\mathrm{Cu}$-pectin precipitation are presented in Table 5 , results showed that good and easily separatable precipitates by centrifugation were obtained when $100 \mathrm{ml}$ of $0.56 \%$ pectin solution was mixed with $20 \mathrm{mg}$ of $\mathrm{Cu}^{2+}$ and then mixture was cooled to $20^{\circ} \mathrm{C}$ and $\mathrm{pH}$ adjusted to 2.8 with concentrated $\mathrm{NH}_{4} \mathrm{OH}$. Yield of $\mathrm{Cu}$-pectin precipitate and their purity are presented in Table 6 . Results revealed that $100 \mathrm{~g}$ of cold leached pomace yielded $21.7 \mathrm{~g}$ of precip. 
Table 4. Batch extraction of pectin from the pomace (cold leached). Results reported are at least average of three replicates.

\begin{tabular}{|c|c|c|c|c|c|c|c|}
\hline \multirow{2}{*}{$\begin{array}{c}\text { Wt. } \\
\text { acidified } \\
\text { water } / W t . \\
\text { pomace }\end{array}$} & \multicolumn{3}{|c|}{ Extraction conditions } & \multirow{2}{*}{$\begin{array}{l}\text { Pectin } \\
\text { content } \\
\text { of sol. } \\
(\%)\end{array}$} & \multirow{2}{*}{$\begin{array}{c}\text { Extract } \\
\text { consistency } \\
\left(t_{s} / t_{0}\right) \\
\end{array}$} & \multirow{2}{*}{$\begin{array}{l}\text { Theor. total } \\
\text { extractable } \\
\text { pectin }^{1)} \\
(\%)\end{array}$} & \multirow{2}{*}{$\begin{array}{l}\text { Pectin } \\
\text { loss in the } \\
\text { residue } \\
(\%)\end{array}$} \\
\hline & $\mathrm{T} \underset{\left({ }^{\prime} \mathrm{C}\right)}{\mathrm{e}} \mathrm{m} p$ & $\mathrm{pH}$ & $\begin{array}{l}\text { Time } \\
\text { (min.) }\end{array}$ & & & & \\
\hline \multirow{11}{*}{60} & \multirow{3}{*}{85} & 1.9 & $\begin{array}{l}20 \\
30 \\
60\end{array}$ & $\begin{array}{l}0.22 \\
0.25 \\
0.28\end{array}$ & $\begin{array}{l}6.4 \\
6.9 \\
6: 5\end{array}$ & $\begin{array}{l}53.6 \\
60.9 \\
68.3\end{array}$ & \multirow{15}{*}{$12-14$} \\
\hline & & 1.7 & $\begin{array}{l}20 \\
30 \\
60\end{array}$ & $\begin{array}{l}0.28 \\
0.30\end{array}$ & $\begin{array}{l}6.5 \\
6.6 \\
7: 2\end{array}$ & $\begin{array}{l}60.9 \\
65.8 \\
73.2\end{array}$ & \\
\hline & & 1.6 & 60 & 0.35 & a. 1 & 85.3 & \\
\hline & \multirow{4}{*}{95} & \multirow[t]{2}{*}{1.9} & $\begin{array}{l}20 \\
30 \\
60 \\
20\end{array}$ & $\begin{array}{l}0.28 \\
0.31 \\
0.36\end{array}$ & $\begin{array}{l}7.1 \\
7.2 \\
6: 8\end{array}$ & $\begin{array}{l}68.3 \\
75.6 \\
87 . \mathrm{a}\end{array}$ & \\
\hline & & & 30 & 0.32 & \multirow{2}{*}{$\begin{array}{l}7.0 \\
7.8 \\
7.5\end{array}$} & \multirow{2}{*}{$\begin{array}{l}78.0 \\
85.3 \\
92.6\end{array}$} & \\
\hline & & 1.7 & 60 & 0.38 & & & \\
\hline & & 1.6 & 60 & 0.4 & 8.6 & 97.5 & \\
\hline & \multirow{4}{*}{100} & 1.9 & $\begin{array}{l}20 \\
30 \\
60 \\
20\end{array}$ & $\begin{array}{l}0.34 \\
0.35 \\
0.38\end{array}$ & \multirow{2}{*}{$\begin{array}{l}5.3 \\
5.5 \\
5.8 \\
4.8 \\
5.3\end{array}$} & $\begin{array}{l}82.9 \\
85.3 \\
92: 6\end{array}$ & \\
\hline & & \multirow{2}{*}{1.7} & 30 & 0.35 & & 85.3 & \\
\hline & & & 60 & 0.40 & $5: 2$ & 97.5 & \\
\hline & & 1.6 & $\begin{array}{r}60 \\
-30\end{array}$ & 0.41 & $\begin{array}{r}4.5 \\
-8.6\end{array}$ & 100.03 & \\
\hline \multirow{4}{*}{40} & \multirow{3}{*}{85} & 1.9 & 45 & 0.38 & \multirow{3}{*}{$\begin{array}{r}7.2 \\
7.5 \\
8.3\end{array}$} & $\begin{array}{l}61.7 \\
65.0\end{array}$ & \\
\hline & & 1.7 & $\begin{array}{l}30 \\
45\end{array}$ & $\begin{array}{l}0.40 \\
0.40 \\
0.42\end{array}$ & & $\begin{array}{l}65.0 \\
68.3\end{array}$ & \\
\hline & & 1.9 & $\begin{array}{l}-30 \\
45\end{array}$ & 0.48 & & 780 & \\
\hline & 95 & 1.7 & $\begin{array}{l}30 \\
45\end{array}$ & $\begin{array}{l}0.52 \\
0.53 \\
0.56 \\
\end{array}$ & $\begin{array}{l}7.5 \\
7.2\end{array}$ & $\begin{array}{l}84.5 \\
86.1 \\
91.0 \\
\end{array}$ & \\
\hline \multirow{3}{*}{30} & 95 & 1.7 & & 0.72 & 12.1 & 87. a & \multirow{3}{*}{$20-21$} \\
\hline & & & $\begin{array}{l}30 \\
45\end{array}$ & 0.74 & 12. a & 90.2 & \\
\hline & 100 & 1.7 & 45 & 0.79 & 9.6 & 96.3 & \\
\hline
\end{tabular}

1) Calculated on the assumption that water retained in the residual peel after extraction of pectin, also contained the same amount of pectin as in the extract.

2) On the basis of theoretical total extractable pectin.

3) $100 \%$ theoretical value.

itates on dry basis of a purity $55.3 \%$. Recovery of pectin in the precipitates on the basis of extracted pectin was $85 \%$.

\section{DISCUSSION}

Total pectin contents of Unshu citrus peel are $15 \%$, compared to 21-22\% reported by Shepherd and Graham (1952) in other citrus, which mean Unshu 
Table 5. Cu-pectin precipitation conditions.

\begin{tabular}{|c|c|c|c|c|c|c|}
\hline \multirow{2}{*}{$\begin{array}{c}\text { wt. } \\
\text { acidified } \\
\text { water/Wt. } \\
\text { pomace }\end{array}$} & \multirow{2}{*}{$\begin{array}{l}\text { Pectin } \\
\text { content } \\
\text { of sol. } \\
\text { (\%) }\end{array}$} & \multicolumn{2}{|c|}{ Precipitation } & \multirow{2}{*}{$\begin{array}{c}\text { conditions } \\
\mathrm{Cu}^{2+} / 100 \mathrm{ml} \\
\mathrm{extract} \\
(\mathrm{mg})\end{array}$} & \multirow[b]{2}{*}{$\begin{array}{l}\text { Nature of } \\
\text { precipitate }\end{array}$} & \multirow[b]{2}{*}{ Remarks } \\
\hline & & $\mathrm{pH}$ & $\begin{array}{l}\text { Temp. } \\
\left({ }^{\circ} \mathrm{C}\right)\end{array}$ & & & \\
\hline \multirow{4}{*}{30} & \multirow{4}{*}{0.74} & \multirow{4}{*}{2.8} & 60 & $\begin{array}{l}15 \\
20 \\
25\end{array}$ & $\begin{array}{l}\text { viscous sol. } \\
\text {-do-- } \\
\text { curd }\end{array}$ & $\begin{array}{l}\text { Incomplete precipitation } \\
\text {-do- } \\
\text { Difficult to handle }\end{array}$ \\
\hline & & & 40 & $\begin{array}{l}20 \\
25\end{array}$ & $\begin{array}{l}\text { very fine } \\
\text {-do- }\end{array}$ & $\begin{array}{c}\text { Difficult to handle } \\
- \text { do- }\end{array}$ \\
\hline & & & \multirow[t]{2}{*}{20} & 20 & easy to separate & $\begin{array}{l}\text { Some ppt. reappear on } \\
\text { addition of excess } \mathrm{Cu}^{2+} \\
\text { in the drain }\end{array}$ \\
\hline & & & & 25 & $-\mathrm{do}-$ & Complete precipitation \\
\hline \multirow[t]{2}{*}{40} & \multirow[t]{2}{*}{0.56} & \multirow[t]{2}{*}{2.8} & \multirow[t]{2}{*}{20} & 20 & easy to separate & $\begin{array}{l}\text { No ppt. on addition of } \\
\text { excess } \mathrm{Cu}^{2+} \text { in the drain }\end{array}$ \\
\hline & & & & 15 & viscous sol. & Incomplete precipitation \\
\hline
\end{tabular}

Table 6. Cu-pectin complex yield and purity (\% dry basis of cold leached pomace). Average of more than four replicates.

\begin{tabular}{|c|c|c|c|c|c|c|}
\hline Pectin content of & Pectin content of & Pectin & \multicolumn{4}{|c|}{$\mathrm{Cu}$-pectin precipitate } \\
\hline $\begin{array}{c}\text { untreated dry peel } \\
\qquad(\%)\end{array}$ & $\begin{array}{c}\text { cold leached pomace } \\
(\%)\end{array}$ & $\begin{array}{c}\text { extracted } \\
(\%)\end{array}$ & $\begin{array}{l}\text { Wt. } \\
(\mathrm{g})\end{array}$ & $\begin{array}{l}\text { Total } \\
\text { pectin } \\
(\%)\end{array}$ & $\begin{array}{c}\text { Purity" } \\
(\%)\end{array}$ & $\begin{array}{c}\text { Recovery }{ }^{21} \\
(\%)\end{array}$ \\
\hline 15.0 & 17. 2 & 14.1 & 21.7 & 12.0 & 55.3 & 85 \\
\hline
\end{tabular}

1) De-coppered pectin.

2) On the basis of $\%$ pectin in the extract.

peel contains about $30 \%$ less pectin than peels being used for pectin manufacture. This difference was more prominent and increased to $50 \%$ and $38 \%$ when Unshu cold leached peel was compared with lime and lemon commercial cold leached peels, evaluated by Rouse and Crandall (1978).

As for quality of pectin is concerned Unshu citrus pomace is equally good as lime and lemon pomace, when compared on the basis of molecular weight, consistency and jelly grade.

Cold and hot leaching washed out $29 \%$ and $40 \%$ of total peel solids respectively, as compared to $20 \%$ by commercial cold leaching. Braddock and Crandall (1978) reported that $30 \%$ total peel solids were removed by applying twice, $1: 2$ peel water washing. Pectin contents increased $17 \%$ and $33 \%$ in case of cold and hot leaching, while Shepherd and Graham (1952) reported $17 \%$ increase after blanching and washing. Unleached peel behaved not well in the oven and turned into dark reddish brown color, similar observations by Crandall et al. (1978) made them to conclude that it is impossible to dry unleached peel as pectin pomace on commercial scale. They further reported that $25 \%$ decrease in quality on basis of 150 grade pectin in case of lemon peel occurred when dried to $8-12 \%$ moisture in direct fire rotary dryer at temper- 
ature of $370535^{\circ} \mathrm{C}$ in first stage and $134-176^{\circ} \mathrm{C}$ in the second stage of dryer, and that loss increased to 54\% when further dried to 3-7\% moisture as compared to only $26 \%$ in our experiment when dried to $3-5 \%$ moisture at $90^{\circ} \mathrm{C}$. These observations clearly indicate that peel should not be dried below $10 \%$ moisture and that up to $10 \%$ moisture quick drying at high temperature have no much degradation effect on the quality of pectin in the pomace.

In case of extraction of pectin from the pomace, a temperature increment of $15^{\circ} \mathrm{C}, \mathrm{pH}$ increment of 0.2 and time increment of 15 minutes in series of pectin extraction experiment showed that most suitable combinations of time, temperature and $\mathrm{pH}$ to get maximum pectin yield were, $\mathrm{pH} 1.6$ at $95^{\circ} \mathrm{C}$ for 60 minutes (yield $97.5 \%$ ) and $\mathrm{pH} 1.7$ at $95^{\circ} \mathrm{C}$ for 45 minutes (yield 91\%). In similar experiments, Myers and Baker (1931), Gaddum (1934) and Rouse and Crandall (1978) tried time increments of 10,20 and $5^{\circ} \mathrm{C}$ respectively. Rouse and Crandall (1978) reported best combination of $\mathrm{pH} 1.6$ at $95^{\circ} \mathrm{C}$ for $30 \mathrm{~min}$ utes in case of lime and lemon pomace when HNO, was used for extraction.

Concentration of pectin extract during pectin manufacture is done by vacuum evaporation (Anonymous, 1967), and aluminum precipitation (Wilson, 1925; Joseph and Havighorst, 1952). Any one of these existing processes if applied as such to pectin manufacture from Unshu citrus pomace, will prove more expensive than imported pectin due to low pectin contents of peel as mentioned earlier. So there is no choice but either to find out a dry process to concentrate pectin in the peel by mechanically separating the pectin rich portion of peel (albedo) or to find out some cheaper methods of concentrating the pectin extract, so as to make it commercially possible to manufacture pectin from Unshu citrus peel. No literature up to now is cited concerning the first choice, whereas, second possibility to find out other economical concentration methods are actively being considered. Concentration of pectin solution by making Cu-pectin complex was tried by Nomura and Naito (1953, 1955) and they reported that yield of $\mathrm{Cu}$-pectin complex was identical with the yield obtained by alcohol precipitation. They further reported that good precipitation results were obtained when equal amounts of pectin extract and $\mathrm{CuCl}_{2}$ solutions (0.07-O. 04\%) were mixed and $\mathrm{pH}$ adjusted at 4.0, as compared to the precipitation conditions in this study using concentrated $\mathrm{CuCl}_{2}$ solution $(20$ $\mathrm{mg} / 100 \mathrm{ml}$ pectin extract), good precipitates were obtained at $\mathrm{pH} 2.8$. Amount of $\mathrm{Cu}^{2+}$ required to precipitate pectin in the extract in both the cases as compared to $\mathrm{Al}^{3+}$ was about $50 \%$ less, moreover, demetaling of precipitate by using IER (ion exchange resin) seems more economical because Cu-pectin complex can easily be changed into solution, which favors quick pick up of $\mathrm{Cu}^{2+}$ by IER. Decoppering of $\mathrm{Cu}$-pectin complex by using IER will be reported in the next publication.

\section{ACKNOWLEDGEMENT}

We are extremely thankful to the administration, Fukuoka-ken Engeiren Amagi Mikan Juice Factory for their kind help in collecting peel samples. 


\section{REFERENCES}

Anonymous 1967 New plant for powdered pectin. Food Manufacture, 42(6): 37-39

AOAC 1960 Methods of Analysis. 9th ed. Assoc. Official Anal. Chem.. Washington D. C.

Braddock, R. J. and P. G. Crandall 1978 Properties and recovery of waste liquids from citrus pectin pomace manufacture. J. Food Sci., 43: 1678-1679

Crandall, P. G., R. J. Braddock and A. H. Rouse 1978 Effect of drying on pectin made from lime and lemon pomace. J. Food Sci., 43: 1680-1682

Gaddum, L. W. 1934 The pectic substances of citrus fruits. Univ. Fla. Agric. Exp. Sta., Bull., 268

Huang, J. M. G. 1973 Improved method for the extraction of pectin. Proc. Fla. State Hort. Soc., 86: 260-261

IFT Committee on Pectin Standardization 1959 Pectin standardization. Final report of the IFT Committee. Food Technol., 13: 496-500

Joseph, G. H. and C. R. Havighorst 1952 Engineering quality pectins. Food Eng., 24(11): $87-89,160-162$

Kaseem, A. A. 1969 The use of ionizing radiation for the hydrolysis of pectins and the effect on the properties of the extracted pectins. Ph. D. thesis, University of Florida, Gainesville, F1.

Kim, W. J., V. N. M. Rao and C. J. B. Smit 1978 Effect of chemical composition on compressive mechanical properties of low ester pectin gels. J. Food Sci., 43: 572-575

Myers, P. B. and G. L. Baker 1931 Fruit jellies 7. The role of pectin 3. Effect of temperature upon the extraction of pectin. Univ. Del. Agric. Exp. Sta.. Bull., 168

Nomura, D. and N. Naito 1953 Fundamental studies on the manufacture of Natsudaidai juice Part 8. On the utilization of the residue (by-products) in process of manufacturing orange juice No. 1. Pectin manufacture by using IER. J. Fermentation Tech., 31: 275-279 (in Japanese)

Nomura, D. and N. Naito 1955 Fundamental studies on the manufacture of Natsudaidai juice Part 15. On the utilization of the residue (by-products) in process of manufacturing orange juice (2) Decopperation of pectin copper salt by cataphoresis. J. Nippon Nogeikagaku Kaishi 29: 412-415 (in Japanes)

Owens, H. S., R. M. McCready, A. D. Shepherd, T. H. Schultz, E. L. Pippen, H. A. Swenson, J, C. Miers, R. F. Erlandsen and W. D. Maclay 1952 Methods for extraction and analysis of pectic materials used at Western Regional Research Laboratory. Pubs. Bureau Agr. Indust. Chem., Agr. Res. Admin., USDA, 340: l-24

Rouse, A. H. 1967 Evaluation of pectins from Florida's citrus peels and cores. The Citrus Ind., 6: 9

Rouse, A. H. 1977 Pectin: distribution, significance. In "Citrus Science and Technology," Vol. 1, Avi Publishing Co. Inc., Westport, pp. 110

Rouse, A. H. and P. G. Crandall 1978 Nitric acid extraction of pectin from citrus peel. J. Food Sci., 43: 72-73

Sakai, T., M. Okushima and K. Ionomura 1978 Enzymic production of pectin from citrus fruit peelings. Proc. 5th. IFT Cong., Kyoto, Japan, Abstracts, 6a-16: 227

Shepherd, A. D. and R. P. Graham 1952 Preparation and evaluation of dried citrus peel as a pectin source material. Food Technol., 6: 411-413

Wilson, C. P. 1925 The manufacture of pectin. Ind.Eng.Chem., 17: 1065-1067 